\title{
AN ANALYSIS OF EDUCATIONAL VALUES IN “TOTTO-CHAN: THE LITTLE GIRL AT THE WINDOW" BY TETSUKO KUROYANAGI BASED ON PAULO FREIRE'S PERSPECTIVE
}

\author{
Jamaluddin ${ }^{1}$ \\ ${ }^{1}$ English Teaching Learning Program, Tarbiyah Faculty, Institut Agama Islam Negeri Madura \\ (jamal.anaksampang@gmail.com) \\ Abd. Ghofur ${ }^{2}$ \\ ${ }^{2}$ English Teaching Learning Program, Tarbiyah Faculty, Institut Agama Islam Negeri Madura \\ (wargastain@yahoo.com)
}

\begin{abstract}
The novel "Totto Chan: The Little Girl at the Window" is a novel in which some parts of its story reflect the concept of education that is unique and different. The concept of education in this novel related to an educational value according to Paulo Freire's perspective. Therefore, this research is mainly purposed to search about what are the educational values found in "Totto Chan: The Little Girl at the Window"? and how educational values appear in "Totto Chan: The Little Girl at the Window" based on Paulo Freire's perspective? This research is a qualitative one by using the content analysis method. Two data sources were chosen, the primary data source is the novel itsself and the secondary data are books, literature, official websites, and other relevant materials. In general, the result found 52 educational values contained in the novel, and 28 educational values based on Paulo Freire's perspective. Those are divided into 6 points: liberating education, pedagogy of the oppressed, dialogic education, the concept of conscientization, contextual education and critical education. Through this research, it is expected that teachers can implement the positive things that exist in this study and in the novels at school and also encourage students' interest in literature.
\end{abstract}

Keywords: Educational Value; Literature; Novel; Paulo Freire

First Received:

(March 11, 2020)
Final Proof Received:

(March 20, 2020)

\section{INTRODUCTION}

The RI Constitution No. 20 in 2003 about National Education System (UU Sistem Pendidikan Nasional) explains that, education was a conscious and deliberate effort to create an atmosphere of learning and the learning process so that learners are actively developing the potential for them to have the spiritual strength of religious, self-control, personality, intelligence, noble character, and skills needed by them, society, nation and state (Undang-Undang Nomor 20 tahun 2003, 2003).

The reality of education in Indonesia apparently is not as beautiful as the education purposes the government declared. It is not only in Indonesia, education in many parts of the world seemed to lose the spirit of 'freedom' in its implementation. Since elementary school, students was designed to be same each-others. Their dresses, books 
and what is taught was the same. It seems that the students led to think the same way each other. The teacher becomes a kind of conductor that connects knowledge with the students. As a recipient of knowledge, students only served to listen, do what the habits of 'good' and behave as expected of them.

Education is like the factory, which produces educational products through educational machines that completely rigid. Education is often practiced as a series of instructions from the teacher to the student. So, education with a model like this will produce a ready-made men required by the headhunter. All students are considered equal in this kind of education model, though each student has a uniqueness and different potentials.

Paulo Freire saw this phenomenon as the relationship between the oppressor and the oppressed. Freire assumed that education must be a path of permanent liberation, and he acknowledged that the process consists of two stages. First, human beings become conscious (aware) about the persecution that happened to him; he should run praxis to change the state of the oppressed. Second, build stability based on what has been done in the first stage; this stage is a permanent process that is filled with cultural actions that liberate (Dale \& Hyslop-Margison, 2010).

The thought of Paulo Freire supported indirectly by Tetsuko Kuroyanagi. Through her novel entitle Totto Chan: A Little Girl at The Window, Tetsuko shows a description of the lives of students named Totto Chan that are limited by the existing education system. If we correlate it with the thought of Freire, Totto Chan in this novel as the oppressed and the teacher in her old school and also the educational system is the oppressor.

In this research, the researcher will analyze a novel entitled "Totto- Chan: The Little Girl at The Window" by Tetsuko Kuroyanagi by using Paulo Freire's perspective about educational value. There are some reasons why the researcher picks up this novel to analyze. First, the researcher think that by reading this novel the readers will know the educational value contained in this novel. Second, the readers will know the educational value in this novel based on Paulo Freire's perspective. Third, the readers can increase their understanding about educational value in interesting way, by reading a novel. Finally, the readers can apply the values consist in the novel in their own lives in the real world. Therefore, An Analysis of Educational Values in "Totto-Chan: The Little Girl at The Window" by Tetsuko Kuroyanagi based on Paulo Freire's Perspective will be very interesting to be studied.

\section{LITERATURE REVIEW}

\section{Literature}

Literature is a rival record of what men have seen in life, what they have experience of it, what they have thought and felt about those aspects of it which have the most immediate and enduring interest for all of us (William, 1913: 10). 
Novel is one of literary works with a more or less complex plot or not pattern of even about human being, their feeling, thought, and human action (Natia, 2010: 42). Novel represents the real world and linked it into imagination world. The relation between those two worlds will bring the readers into the new world that full of stuffs.

\section{Educational Values}

a. Education

Crow (in Natia, 2010) said that education is a process which contain some activities for an individual to social life and help continue the tradition and culture and also social institution from generation to generation. Individual and social life cannot be separated from education. Both connected and synergize each other, mutual support for the development of learners. Applying the values of society needs to be done so that education that occurred not only glued in a mere formality, but is also capable of forming individuals who are ready to interact with the community.

b. Value

There are some definition of value comes from references the researcher get. Kluckhohn said that values are conceptions, explicit or implicit, distinctive of an individual or characteristic of a group, of the desirable which influence the selection from available mode, means, and ends of action (Haydon, 2007: 8). Shaver and Strong said that values are our standards and principles for judging worth. They are the criteria by which we judge things to be good, worthwhile, desirable, or on other hand, bad worthless despicable (Halstead \& Taylor, 2005: 5).

c. Educational Values

Sastrapreteja states that educational value is the cultivation and development of values in a person. Mardimadja defines the educational value as an aid to the learners to realize and experience the values and place them integral to his whole life (Mubarak, 2008). Educational values are the results of valuing process of comprehension and implementing of God and humanity values in life. So, these values will guide human knowledge and creativity appropriately.

\section{Relation between Literature and Education}

According to Collie and Slater, one of the aims of teaching literature is to encourage learners to feel that they can read and enjoy books on their own (Collie \& Slater, 1992: 12). Reading literature can make students understand the wider world. Students do not only enjoy literature they read, the values contained in it will also be absorbed by them.

\section{Biography of Tesuko Kuroyanagi}

Tetsuko Kuroyanagi was born on August 9, 1933 in Tokyo, Japan and she is a famous person. She was born in Tokyo. Tetsuko Kuroyanagi is the daughter of a celebrated 
Jamaluddin, and Abd. Ghofur, An Analysis of Educational Values in ...

violinist. She becomes the chief of opera at the Tokyo College of Music and then trained in theatre at Tokyo's Bungakuza Theatre and in New York at the Mary Tarcai Studio. Her childhood memoir, Totto-chan: The Little Girl at the Window has sold more than 7 million copies. With royalties from her book sales she established the Totto Foundation to train professional actors with hearing impairments. She is also the author of Totto Chan's Children: A Goodwill Journey to the Children of the World based on her UNICEF missions ("Goodwill Ambassador | UNICEF People | UNICEF," 2014).

\section{Paulo Freire and His Perspective}

Freire's concept of education up to now remained suitable for continuously studied and developed. It is indeed a challenging idea, though expressed in a simple style, and keep it open to test its validity according to the reality of time, place, and those in which it is applied (Freire, 2004). There are six concepts of education according to Paulo Freire, they are as follow:

\section{Liberating Education}

Freire says that education is the most vital value to the process of human liberation. For him, education becomes a permanent path of liberation, and it is in two stages. First, education makes people aware of their oppression and through practical action to change the situation. Second, education is a process of permanent liberation of cultural action. Freire (1973: 190) says that education at this level should be a process of liberation (humanization), not taming (domestication) socially as often happens in the third world countries (such as Brazil), which is often used as educational tool to legitimize the ruler against the will of the people who are not in power. For that, education should be a thorough reflection and action to transform the oppressive reality of liberation.

\section{a. Pedagogy of Oppressed}

Freire's liberation discourse is based on individual beliefs and political transformation. He emphasized that the structures, systems, or institutions of oppression must be rejected. Freire describes the oppression as a condition in which A objectively exploits B or hinders their efforts to assert themselves as a responsible person. For Freire, the suffering of the poor is not accidental only, but also as a result of oppression from unjust structures. Freire's mind starts from Karl Marx's analysis of class conflict (class struggle), also from the liberation theology which assumes that we should pro-poor (Risakotta \& Bernhar, 2001).

Dehumanization, according to Freire, although a concrete historical fact, is not the fate that fell from the sky, but the result of an unjust order that led to the violence at the hands of the oppressors, which in turn dehumanized the oppressed. Freire believes that a fair order of society, the system of norms, procedures, and legal authority to force individuals to believe that poverty and injustice are the inevitable fact of human life; that 
this unjust order has been putting power in the middle of a few people and put myths in the minds of all people.

Freire warned that the status, power, and domination of oppressors would be impossible without the existence of the oppressed. Between oppressors and oppressed is a manifestation of the behaviour of dehumanization (A. S. William, 2001: 70). The oppressor dehumanized by act of oppression that would destroy themselves, while the oppressed dehumanized. By the reality of oppression they experience. Oppression is not only about the physical, but also penetrated into the depths of the psyche and human consciousness. Precisely that most human beings are driven and manipulated by the power of the oppressors who previously unaware. And the task of education is primarily liberates human from the oppression.

b. Dialogic Education

Dialogic education is Freire's rejection of 'banking style of education'. In dialogic education the teacher and the student must be a dialogue partner in solving all problems, not create distance between teachers and students, because with the distance will make the opportunity of the suppression of the teachers to the students is wide open. Therefore, the only the most effective tools in a humane education (humanist) is the reciprocal relationship in the form of a permanent dialogue (Freire, 1970: 275).

Essentially Freire defined dialogue as a language/word, arranged on the reflection and action. Spoken words without actions are verbal, and action without reflection is activism. Dialogue is hopeful a revolutionary act, as empirical knowledge met with critical knowledge. Through dialogue and communication language, students are considered responsible for their own learning process, and then they become critical coInvestigators in dialogue with the teacher (Freire, 1970: 275).

In an educational forum where memorized facts selected by others are considered to be evidence of intelligence, the capabilities that are necessary to engage fully in democratic processes are suppressed. The role of students is adjusting to external expectations because knowledge and power are things possessed by others. Thus, in spite of an abundance of rhetoric to the contrary, the operational goal of education is not the transformation of the individual, or even the creation of "good citizens" but a replication of the socioeconomic, political, and cultural status quo. Freire (in Dale \& Margison, 2010: 98) believed that a dialogic classroom begins the transformation of nondialogic "subjects" into critically conscious subjects in the process of becoming.

Furthermore, Freire insists that dialogue is essential to the process of awakening. He underlined the vast potential of the dialogue and with the spirit maintains the power of language as a tool that is able to inculcate domination and freedom. Of course, the dialogue can bring someone to interpret the world and encourage the social transformation and liberation. Freire also shamelessly hold values such as love as the 
essence of the dialogue; "If I do not love the world; if I do not love life; if I do not love people, I cannot enter into dialogue".

Context of theoretical dialogue basically presenting the facts in the form of real situation that can be analyzed critically. The analysis included tests of abstraction in a way represents the reality of concrete, especially in the search for knowledge is contextual. As an object of knowledge, codification became media descriptors in investigating the subject of knowledge, i.e, between teachers and students in investigating dialogical object. This happened in the practical stage, and will automatically include decodificated, in terms of critical reflection on the knowledge objects into their communication bridge. Decodificated objective is to achieve a level of critical knowledge that linguistic discourse that should be read by everyone who wants to interpret it.

\section{The Concept of Conscientization in Education}

Conscientization is the understanding of the real situation that the students have. Daniel Schipani (1996: 307-308) explains conscientization of Freire as follows:

"Denotes an integrated process of liberative learning and teaching as well as personal and societal transformation. Conscientization thus names the process of emerging critical consciousness whereby people become aware of the historical forces that shape their lives as well as their potential for freedom and creativity; the term also connotes the actual movement toward liberation and human emergence in persons, communities, and societies."

Conscientization is an understanding of the real situation that is being experienced by the students or pupils. Although the last region you want to target is systemic change, but Freire education aimed at liberation and humanization. In order that Freire saw conscientization as the core of education. Education should aim to sensitize students to the reality of social (A. S. William, 2001: 68).

Freire (1979: 96) divides human consciousness into magical consciousness, naive, and critical. First, awareness of the magical (magical consciousness) is the consciousness of people who are unable to see the link between the factors with other factors. For example, poor people are not able to see the link between their poverty with the political system and culture.

Second, naive consciousness (naival consciousness) is more look into the root causes of human aspects in society. In this awareness, ethical issues, creativity, need for achievement regarded as a determinant of social change.

Third, critical consciousness which focuses on the structural aspects of the system and as a source of the problem. Education tried to critically analyze the structure of the system and the social, political, economic, cultural, and other community contexts. 


\section{a. Contextual Education}

Freire emphasizes the role of thinking in re-making the world. From social facts can be revealed through education, and according to Freire, should be pursued their unification (integration) world fact (real) into the world of education. If during the education made a myth of reality of the world to cover the actual reality, then the contextual education system (facing problems) should be made social reality as demythology. Contextual Education fosters human interaction with his world, because the task is problematization contextual education became part of the social reality of man as learners. Education is the process by which we give names to the real world (Freire, 2004). Indirectly, Freire's theory of positivism dismantles Western science that assumes that knowledge is something positive, fixed and definite.

To that end, in his pedagogy, Freire made three schemes in formulating educational context. First, the investigation, the testing and discovery of human consciousness superstitious, naive, and critical. Second, thematization, i.e testing the thematic universe by reduction; discovery generative themes are new, which is implied in the previous themes. Third, problematization, the discovery of complex situations and actions lead to a practical limit authentic permanent cultural action for liberation (Collins, 2006: 49).

\section{b. Critical Education}

From all this, it seems that one advantage is its ability Freire stands between theory and practice. On the one hand, Freire does not fall in the extreme development of a dry sort of philosophy of education, and on the other hand, despite the pragmatic activities, with trips and visits to various regions, it does not fall on or be driving political activism. Things like that are what often make it difficult to classify the Freire in a clear position. Freire as meet both these criteria, critics and praxis, or at all neither. Freire as quoted by Dale \& Margison (2010: 4) describes the importance of dialogue as follows:

"Founding itself upon love, humility, and faith, dialogue becomes a horizontal relationship of which mutual trust between the dialoguers is the logical consequence. It would be a contradiction in terms if dialogue-loving, humble, and full of faith-did not produce this climate of mutual trust, which leads the dialoguers into ever closer partnership in the naming of the world."

Critically minded teachers troubled by the injustices around them are attracted to Freire's dialogical pedagogy with its compelling emphasis on student-centered learning, revealing the relationship between personal struggles and social injustice, and ultimate structural transformation.

\section{Previous Study}

To make sure that this research is original, the writer would like to present others research that has close relation with the study. There are two researches related to this study. The first research is The Analysis of Educational Values in "By the River Piedra I Sat 
Jamaluddin, and Abd. Ghofur, An Analysis of Educational Values in ...

Down and Wept" Novel by Paulo Coelho on John S. Brubacher's Perspective written by Fatahillah Erfan (2012). The second research is An Analysis of Educational Values in Tetsuko Kuroyanagi's Novel Entitle Totto-Chan: The Little Girl at The Window written by Fardhian Hartanto (2012).

\section{METHOD}

The research approach that is used in this study is qualitative approach. Creswell state that qualitative research is an inquiry approach useful for exploring and understanding a central phenomenon (Creswell, 2012: 626). It's mean that qualitative research is one of approach which is aimed at finding out the quality of a particular phenomenon. Qualitative produces descriptive data in written or spoken form, and qualitative typically involves words. The research method applied in this study is content analysis. According to Donald Ary content analysis focuses on analyzing and interpreting recorded material to learn about human behavior. Content or document analysis is a research method applied to written or visual materials for the purpose of identifying specified characteristics of the material. The materials may be public records, textbooks, letters, films, tapes, diaries, themes, reports, or other documents. Content analysis usually begins with a question that the researcher believes can be answered by studying documents (Ary, Jacobs \& Razavieh, 2010: 29).

The subject of this research is the researcher himself and the novel of Totto-Chan: The Little Girl at The Window by Tetsuko Kuroyanagi. The researcher investigates the educational values that appear in Totto- Chan: The Little Girl at The Window by Tetsuko Kuroyanagi. The sources of this research consist of primary and secondary sources (Arikunto, 2010: 129). Data source in this study are divided into primary and secondary source. The primary source in this study is the novel Totto-chan: The Little Girl at the Window, and the Secondary sources are taken from any kinds of books, literatures, official websites and other relevant materials.

Novel is the instrument for researcher to search the educational value. To collect the data, the researcher uses text observation. It means the researcher wants to describe the educational values that occur in Totto- chan: The Little Girl at the Window novel written by Tetsuko Kuroyanagi.

The next step is data analysis, it is identifying and selecting individual for a study, obtaining their permission to study them, and gathering information by asking people questions or observing their behaviours (Creswell, 2012: 9). The procedure that used by researcher to collect the data are observation. The data of the research is collected by doing the following steps: selecting the novel, reading the novel repetitively and carefully, identifying to find the data related to the study, selecting the relevant data, and reporting selected data. 
This research applied six steps involved in analyzing and interpreting qualitative data proposed by Creswell (Creswell, 2012: 262). The six of them are the first, preparing and organizing the data for analysis. The second is exploring and coding the data. The third is coding to build descriptions and themes. The fourth is representing and reporting qualitative findings. The fifth is interpreting the findings. The last is validating the accuracy of the findings.

\section{RESULTS AND DISCUSSION}

The researcher analyzed the educational values in Tetsuko Kuroyanagi's novel entitled Totto Chan: A Little Girl at the Window. The researcher analyzed the novel based on Paulo Freire's perspective about education. To make the readers easier to understand, the researcher divides the discussion into six parts. There are six concepts in education according to Paulo Freire as following:

\section{Liberating Education}

There are seven educational values in this novel that suitable with the concept of liberating education based on Paulo Freire's perspective.

"Totto-chan hadn't learned how to tell time yet, but it did seem like a rather long time. If she had been able to, she would have been astonished, and even more grateful to the headmaster. For, you see, Mother and Totto-chan arrived at the school at eight, and when she had finished talking and the headmaster had told her she was a pupil of the school, he looked at his pocket watch and said, "Ah, it's time for lunch." So the headmaster must have listened to Totto-chan for four solid hours!" (Kuroyanagi, 1981: 8).

Adults often do not provide the opportunity for children to express their thoughts. Though the children are also human beings who have a tendency to speak and be listened. Principals provide an example for us to listen to anybody, including children. As a teacher in charge of educating students, listening to students' opinions is very important to do.

"Going to school in a railroad car seemed unusual enough, but the seating arrangements turned out to be unusual, too. At the other school each pupil was assigned a specific desk. But here they were allowed to sit anywhere they liked at any time (Kuroyanagi, 1981: 11)."

Such Liberation will train students to be flexible in all situations. Students will understand better about the lessons in the classroom because they chose a seat in accordance with their wishes, so that they are comfortable and ready to receive lessons.

"Schools normally schedule one subject, for example, Japanese, the first period, when you just do Japanese; then, say, arithmetic the second period, when you just do arithmetic. But here it was quite different. At the beginning of the first period, the teacher made a list of all the problems and questions in the subjects to be studied that day. Then she would say, "Now, start with any of these you like (Kuroyanagi, 1981: 12)." 
The selection of the subject based on the agreement of all the students in the class. Thus, students will learn to consult with the other students. Students will also learn to make choices. These things will be useful for students when they have to face the real world with full of challenges.

"The pile was a real mountain by now and the tank was almost empty, but there was still no sign of the purse. Maybe it had stuck to the rim of the tank or to the bottom. But Totto-chan didn't care. She was satisfied she had done all she could. Totto-chan's satisfaction was undoubtedly due in part to the self-respect the headmaster made her feel by not scolding her and by trusting her. But that was too complicated for Tottochan to realize then (Kuroyanagi, 1981: 21)."

The headmaster believed in Totto Chan. He left Totto Chan alone without worrying that Totto Chan will forget the commitment to make everything as usual. This makes Totto Chan unencumbered while looking for her purse. Totto Chan who gains the trust of the headmaster put things right after she finished.

"This is your library," the headmaster said. "Any of these books may be read by anyone. You needn't fear that some books are reserved for certain grades, or anything like that. You can come in here any time you like. If you want to borrow a book and take it home, you may. When you've read it, be sure and bring it back! And if you've got any books at home you think the others would like to read, I'd be delighted if you'd bring them here. At any rate, please do as much reading as you can (Kuroyanagi, 1981: 61)."

Students may go to the library whenever they want. There is no class limit to read a book. Everything is treated equally. Students may also borrow a book and take it home as long as they are return the book to the library after reading the book.

"At Tomoe, where the children were allowed to work on their subjects in any order they pleased, it would have been awkward if the children let themselves be disturbed by what others were doing. They were trained to concentrate no matter what was going on around them. So nobody paid any attention to the child singing aloud while drawing the hausfrau. One or two had joined in, but all the others were absorbed in their books (Kuroyanagi, 1981: 61)."

Students who are reading the book did not feel disturbed. That's because at Tomoe Gakuen students have become accustomed to doing whatever they want. So they have been trained to concentrate despite of the very diverse. The ability to concentrate in a situation that is not conducive can be useful in the future. Tomoe Gakuen students acquire these skills naturally through habituation in school, without the direction or force.

"Writing on the floor with chalk was the head-master's idea. Paper wasn't big enough and there weren't enough blackboards to go around. He thought the Assembly Hall floor would make a nice big blackboard on which the children could note the rhythm with ease no matter how fast the music was, and writing as large as they liked, Above all, they could enjoy the music. And if there was time afterward, they could draw 
airplanes and dolls and anything they wanted. Sometimes the children would join up their drawings just for fun and the whole floor would become one enormous picture (Kuroyanagi, 1981: 84-85)."

By making the floor as the board, the children can draw a rhythm even with fast music. This will allow the children to remember the rhythm, because they write it on a blackboard which is quite wide. In addition to training students' ability to recognize the tone, in this way, students also train their kinaesthetic ability.

\section{Pedagogy of the Oppressed}

There are six educational values in this novel that suitable with the concept of pedagogy of the oppressed based on Paulo Freire's perspective.

"Mother did not tell Totto-chan she had been expelled. She realized Totto-chan wouldn't understand what she had done wrong and she didn't want her to get any complexes, so she decided not to tell Totto-chan until she was grown-up. All Mother said was, "How would you like to go to a new school! I've heard of a very nice one (Kuroyanagi, 1981: 5)."

Based on the ideas of Paulo Freire, Totto Chan is the oppressed who were in the neighbourhood and the system of the oppressor. The education system in her old school assumes that students are good is that always follow the rules, always follow the orders of the teacher, and do the same thing as is done by all students. Totto Chan was doing the opposite.

"You might wonder why the headmaster allowed the children to swim naked. There were no rules about it. If you brought your suit and wanted to wear it, that was perfectly all right. On the other hand, like today, when you suddenly decided to go in and hadn't a suit, that was perfectly all right, too. And why did he let them swim in the nude! Because he thought it wasn't right for boys and girls to be morbidly curious about the differences in their bodies, and he thought it was unnatural for people to take such pains to hide their bodies from other people (Kuroyanagi, 1981: 26)."

By freeing students whether wear suit or not in the pool, the headmaster wants students with physical limitations to be more confident with their body. Physical limitations often make a person become the oppressed. But at Tomoe Gakuen, such a thing is not happened because every student can appreciate students with disabilities.

"As all kinds of things were done differently at Tomoe, its Sports Day, too, was unique. The only sports events that were the same as at other elementary schools were the Tug of War and the Three Legged Race. All the rest had been invented by the headmaster. Requiring no special or elaborate equipment, they made use of familiar everyday school things (Kuroyanagi, 1981: 48)." 
The headmaster does this so that children with special needs can also follow the race on sports day. By holding a race which is a reflection of daily activities at school, students who have physical limitations can participate.

"Drying her eye, Mother said to Totto-chan very slowly, "You're Japanese and Masao chan comes from a country called Korea. But he's a child, just like you. So, Totto chan dear, don't ever think of people as different. Don't think, 'That person's a Japanese, or this person's a Korean.' Be nice to Masao-chan. It's so sad that some people think other people aren't nice just because they're Koreans. (Kuroyanagi, 1981: 57)"

Her mother knew that Masao do it because of people around him. Totto Chan's mother gave understanding to Totto Chan that Masao, regardless of where he came from, was a child as well as Totto Chan. Assume that someone does not good just because of he's Korean is really pathetic.

"I'm sorry I pulled them," he said in a loud, flat voice. "I've been scolded by the headmaster. He said you've got to be nice to girls. He said to be gentle with girls and look after them."

"Totto-chan was somewhat amazed. She had never heard anyone before say you had to be nice to girls. Boys were always the important ones. In the families she knew where there were lots of children,-it was always the boys who were served first at meals and at snack time, and when girls spoke, their mothers would say, "Little girls should be seen and not heard (Kuroyanagi, 1981: 59)."

The headmaster applies the pedagogy of the Oppressed. The headmaster is no longer assumes that boys and girls should be treated differently. The headmaster even treats girls better. He asked Oe to be gentle with girls and look after them.

"Daddy knew Totto-chan had barely enough to eat and was vainly putting money in the caramel vending machine every day. He also knew that the gifts of food he would receive for playing a few wartime tunes would be very handy for his family. But Daddy valued his music even more. Mother knew that, too, and so she never urged him to do it. "Forgive me, Totsky!" said Daddy, sadly (Kuroyanagi, 1981: 89)."

\section{Dialogic Education}

There are four educational values in this novel that suitable with the concept of dialogic education based on Paulo Freire's perspective.

"The headmaster then addressed the whole school, "Where does denbu come from, the ocean or the hills? (Kuroyanagi, 1981: 14)."

The headmaster has applied dialogic education. The headmaster can actually teach students about the differences of seafood and land food in the classroom. But, the headmaster selected to give an explanation at lunch. The headmaster starts with a question that is addressed to all students, followed by giving an explanation after the students expressing their opinions about where denbu derived. 
"You needn't worry about trying to be a good speaker," he said. "And you can talk about anything you like. You can talk about things you'd like to do. Anything. At any rate, let's give it a try (Kuroyanagi, 1981: 45)."

The headmaster told students not to worry about anything. The headmaster said that the students can talk whatever they want to say. The headmaster at Tomoe Gakuen realizes that there are students who struggle to communicate something through talks.

"Totto-chan never forgot how the headmaster had reprimanded their homeroom teacher in his kitchen and not in the faculty room, where the other teachers were. It showed he was an educator in the very best sense of the word, although Totto-chan did not realize that at the time. The sound of his voice and his words remained in her heart forever (Kuroyanagi, 1981: 63)."

The headmaster engages in dialogue with the homeroom teacher. He also said the possibilities about what will happen in Takahashi because the words from the homeroom teacher. Homeroom teacher cried then. She cried was not because summoned by the principal, but she feel guilty about Takahashi.

"Totto-chan was dumb founded. Not because he was against her being a spy. But because everything Tai-chan said was true. They were all things she had suspected. She realized then that in every respect she lacked the talents a spy needed. She knew, of course, that Tai-chan had not said those things out of spite. There was nothing to do but give up the idea. It was just as well she had talked it over with him (Kuroyanagi, 1981: 87)."

Totto Chan admitted that what was said by Tai chan was true. Totto Chan know that Tai Chan said like that was not because he does not want Totto Chan became a spy. After a dialogue with Tai chan, Totto Chan recognizes that she does not have the talent to be a spy.

\section{The Concept of Conscientization in Education}

There are six educational values in this novel that suitable with the concept of conscientization education based on Paulo Freire's perspective.

"The headmaster had adopted the phrase to describe a balanced meal--the kind of food he expected you to bring for lunch in addition to your rice. Instead of the usual "Train your children to eat everything," and "Please see that they bring a nutritiously balanced lunch," this headmaster asked parents to include in their children's lunchboxes "something from the ocean and something from the hills (Kuroyanagi, 1981: 13)."

The headmaster has applied conscientization in lunch time. Students learn to recognize two types of food that they may have never known before. Students will also be spared from the likes, only one type of food. Students will be realized that food, wherever it is, still a good meal to eat. With this rule, the children will try the food that they had never known. 
"Well; I'd better go and bring back the rest of the ghosts," said Mr. Maruyama, the fifth grade home-room teacher, setting off. He rounded up ghosts he found standing bewildered under street lights, and ghosts who had been so frightened they had gone home. He brought them all back to the school. After that night Tomoe students weren't frightened of ghosts anymore. For, after all, even ghosts themselves get frightened, don't they? (Kuroyanagi, 1981: 33)"

The concept of consientization plays its role. By doing this game, the headmaster wants to demonstrate to students that there is no need to fear. Student whom is previously afraid of ghost, after following this game, are more daring than ever. By using their friends as a ghost, students will think if there is nothing to be afraid about ghost.

"Totto-chan was rather sorry, but the headmaster was in trouble, so she had agreed. Another reason was that the thought of a grown-up man--her beloved headmaster searching high and low in all the ribbon shops, made her feel sorry for him. That was the way it was at Tomoe. Without realizing it, everyone got in the habit of understanding one another's problems and trying to help, irrespective of age. It became the natural thing to do (Kuroyanagi, 1981: 75)."

Totto Chan happily no longer wear the ribbon to school, so Yumi will stop asking the headmaster to bought her the ribbon. Totto Chan, as well as other students at Tomoe Gakuen, is easier to understand the suffering of others even if they are still children. As the concept of conscientization, the students understand the real situation that is happening around them.

"For the first time in her life Totto-chan visited a hospital for wounded soldiers. She went with about thirty elementary school children from various schools, children she didn't know. It was part of a scheme recently organized nationally for groups of elementary school children. Each school would normally send two or three children, but small schools like Tomoe only sent one, and the group would be in the charge of a teacher from one of the schools. Totto- chan was representing Tomoe (Kuroyanagi, 1981: 75)."

Conscientization contained in this text. Totto Chan as a representative of Tomoe Gakuen along with students from other schools directly sees the circumstances of the soldiers at the hospital. Through interacting with the soldiers, children, though still a child, will be aware of the circumstances of the soldiers who kept fighting for the country.

"Totto-chan and her friends learned lots of things about America. Japan and America were becoming friends at Tomoe. But outside Tomoe, America had become an enemy, and since English had become an enemy language, it was dropped from the curriculum of all the schools.

"Americans are devils," the government announced. But at Tomoe the children kept chanting in chorus, "Utsukushii is beautiful." And the breezes that blew across Tomoe were soft and warm, and the children themselves were beautiful (Kuroyanagi, 1981: 82)." 
Most people assume that the America was not good, but Tomoe Gakuen students assume that they American friend in the class are very pleasant. Their new fiend from America is a good boy. He teaches others about English as well as the others teach him about Japan language. The conscientization play its role.

"In this way Tomoe children learned what trouble cleaning off graffiti could be, so they never scribbled anywhere except on the floor of the Assembly Hall. Moreover, this class took place about twice a week, so the children had their fill of scribbling (Kuroyanagi, 1981: 85)."

This text consists of conscientization. The students will understand about the trouble of making graffiti. The students remove images that they made on the floor after the lesson is completed. So that the students know how is difficult to delete the image. Then students will not draw like that except in the Assembly Hall when the music lesson.

\section{Contextual Education}

There are five educational values in this novel that suitable with the concept of contextual education based on Paulo Freire's perspective.

"After they had walked for about ten minutes, the teacher stopped. She pointed to some yellow flowers, and said, "Look at these mustard flowers. Do you know why flowers bloom?"

"She explained about pistils and stamens while the children crouched bythe road and examined the flowers. The teacher told them how butterflies helped flowers bloom. And, indeed, the butterflies seemed very busy helping (Kuroyanagi, 1981: 16)."

The teacher implemented contextual education to students this way. By leading the students outside the class and showing the real flowers, the student will be understand more. The real experience like this is more powerful to make students understand about the flowers and how the flowers bloom.

"Some of the children lay in their tents with just their heads showing, while others sat up properly, and some lay with their heads on older children's laps, all listening to his tales of foreign countries they had never seen and sometimes never even heard of. The headmaster's stories were fascinating, and at times they felt as if the children described in lands across the sea were friends. And so it happened that this simple event--sleeping in tents in the Assembly Hall--became for the children a happy and valuable experience they would never forget. The headmaster certainly knew how to make children happy (Kuroyanagi, 1981: 28)."

The headmaster implemented contextual education in order to teach students about independently, adaptation to a new place and situation, and cooperate with others. He use camping for this, that makes students very enthusiasm and feel no force to receive the message the headmaster want to deliver.

"The children considered "their" trees their own private property, so if you wanted to climb someone else's tree you had to ask their permission very politely, saying, "Excuse me, may I come in! (Kuroyanagi, 1981: 29)." 
By making students as subjects who had a tree in the school, the headmaster has been applied the contextual education. Indirectly, the students will learn to maintain and be responsible for the tree itself, asking for permission to climb the tree of other students, and to respect other students' tree.

"Unlike camping inside the school and the Bravery Test, the three- day stay at Toi Spa was a real-life experience. For example, they were sent in turns to buy vegetables and fish for dinner, and when strangers asked them what school they went to and where they were from, they had to answer politely. Some of the children nearly got lost in the woods. Others swam so far they couldn't get back and had everyone worried. Others cut their feet on broken glass on the beach. In each case everyone had to do their best to help (Kuroyanagi, 1981: 36)."

This is related with the contextual education that integrated the world fact into the world of education. The children will learn the social skill needed in their future life, such as: interact with people when buying vegetables for dinner, talking with strangers, the difficulties in the outside and the important of help others.

"Besides teaching the children how to plant a field, the farming teacher told them interesting things about insects, birds, and butterflies, about the weather, and about all sorts of other things. His strong gnarled hands seemed to attest that everything he told the children, he had found out himself through experience (Kuroyanagi, 1981: 67)."

Totto chan and her friends in Tomoe Gakuen have a new farming teacher. He teaches about planting, small animals in school, weather and some interesting things. He is a farmer. That makes him easy to introduce the nature to the children of Tomoe Gakuen. Contextual education belongs to this text.

\section{Critical Education}

There are no educational values in this novel that suitable with the concept of critical education based on Paulo Freire's perspective.

\section{CONCLUSION}

The educational values consist in Totto Chan: A Little Girl at The Window novel are 52 educational values. The majority of existing educational values derived from the headmaster and Tomoe Gakuen school, while others emerged from Totto Chan's family and the people who have ever encountered with Totto Chan. From the educational values were found in Totto Chan: A Little Girl at the Window, the researcher found 28 educational values which are suitable with the Paulo Freire's perspective about education. There are seven educational values that suitable with the concept of liberating education: six educational values about pedagogy of the oppressed, four educational values about dialogic education, six educational values in accordance with the conscientization education, five educational values about contextual education, and there is no educational values about critical education. 


\section{REFERENCES}

Arikunto, S. (2010). Prosedur Penelitian Suatu Pendekatan Praktik. Jakarta: Rineka Cipta.

Ary, D., Jacobs, L. C., \& Razavieh, A., (2010). Introduction to research in education (8th ed). Belmont, CA: Wadsworth.

Collie, J., \& Slater, S. (1992). Literature in the Language Classroom: A Resource Book of Ideas and Activities. Cambridge: Cambridge University Press.

Collins, D. E. (2006). Paulo Freire: Kehidupan, Karya, dan Pemikiran. Yogyakarta: Pustaka Pelajar.

Creswell, J. W. (2012). Education Research. Boston: Pearson Education.

Dale, J., \& Hyslop-Margison, E. J. (2010). Paulo Freire: Teaching for Freedom and Transformation: The Philosophical Influences on the Work of Paulo Freire. Berlin: Springer Science \& Business Media.

Dale, J., \& Margison, E. J. H. (2010). Paulo Freire: Teaching for Freedom and Transformation: The Philosophical Influences on the Work of Paulo Freire. Berlin: Springer Science \& Business Media.

Erfan, F. (2012). The Analysis of Educational Values in "By the River Piedra I Sat Down and Wept" Novel by Paulo Coelho on John S. Brubacher's Perspective (Skripsi). STAIN Pamekasan.

Freire, P. (1970). Cultural Action for Freedom. Massachusetts: Harvard Educational Review and Center for Study of Development and Social Change.

Freire, P. (1973). Education as the Practice of Freedom in Education for Critical Conciousness. New York: Continium.

Freire, P. (1979). Education for Critical Consciousness. London: Sheed and Ward.

Freire, P. (2004). Politik Pendidikan (A. Prihantoro \& F. A. Fudiyantoro, Trans.). Yogyakarta: Pustaka Pelajar.

Goodwill Ambassador | UNICEF People | UNICEF. (2014). Retrieved March 11, 2020, from https://www.unicef.org/people/people_tetsuko_kuroyanagi.html

Halstead, J. M., \& Taylor, M. J. (2005). Values in Education and Education in Values. London: Taylor and Francis, Routledge.

Hartanto, F. (2012). An Analysis of Educational Values in Tetsuko Kuroyanagi's Novel Entitle Totto-Chan: The Little Girl at The Window. STAIN Salatiga, Salatiga.

Haydon, G. (2007). Values for Educational Leadership. London: SAGE Publications Ltd.

Kuroyanagi, T. (1981). Totto-Chan: The Little Girl at the Window. Tokyo: Kodansa.

Mubarak, Z. E. (2008). Membumikan Pendidikan Nilai. Bandung: Alfabeta.

Natia, I. K. (2010). Apresiasi Sastra. Surabaya: Bintang Surabaya.

Republik Indonesia. Undang-Undang Nomor 20 tahun 2003 tentang Sistem Pendidikan Nasional. , (2003).

Risakotta, A., \& Bernhar. (2001, February). Pendidikan Kritis Yang Membebaskan. Presented at the Basis Nomor 01-01 Tahun Ke-50. 
Jamaluddin, and Abd. Ghofur, An Analysis of Educational Values in ...

Schipani, D. (1996). Liberation Theology and Religious Education. In R. C. Miller, Religious Education. Birmingham.

William, A. S. (2001). Conscientizacou Tujuan Pendidikan Paulo Freire (A. Prihantoro, Trans.). Yogyakarta: Pustaka Pelajar.

William, H. H. (1913). An Introduction to The Study of Literature (2nd ed.). London: Enlarge Publisher. 